\title{
New findings reveal that the Middle Triassic ichthyosaur Mixosaurus cornalianus is the oldest amniote with a dorsal fin
}

Silvio Renesto, Cristiano Dal Sasso, Fabio Fogliazza, and Cinzia Ragni

Acta Palaeontologica Polonica 65 (3), 2020: 511-522 doi:https://doi.org/10.4202/app.00731.2020

Two excellently preserved specimens of Mixosaurus cornalianus from the Anisian layers of the Middle Triassic Formazione di Besano, with soft parts associated with well-articulated skeletal elements, revealed the presence in this species of a dorsal fin and of a well-developed, triangular dorsal lobe of the caudal fin, both stiffened by an array of fibre bundles, as in Jurassic fast-swimming ichthyosaurs. This finding testifies that efficient swimming exaptations were already present in some Middle Triassic ichthyosaurs. Mixosaurus is then the oldest amniote so far known that developed a dorsal fin. The preservation of the fin shapes, scaleless skin, and three-dimensional dermal fibres is remarkable, allowing observation of their microstructure, and ruling out any artefactual interpretation. Stomach contents indicate that both specimens preyed upon cephalopods and small fishes. An internal organ, possibly a tract of the intestine, is also preserved in one specimen, which represents the first documented case in the ichthyosaurs of the Besano Formation, and a rarity in the fossil record of the clade.

Key words: Ichthyosauria, Mixosauridae, soft tissue preservation, functional morphology, Mesozoic, Italy.

Silvio Renesto [silvio.renesto@uninsubria.it, ORCID: https://orcid.org/0000-0002-8845-5717], Department of Theoretical and Applied Sciences, Università degli Studi dell'Insubria, via Dunant 3, Varese Italy. Cristiano Dal Sasso [Cristiano.DalSasso@comune.milano.it ] and Fabio Fogliazza [Fabio.Fogliazza@ comune.milano.it], Museo di Storia Naturale di Milano, Corso Venezia 55, Milano, Italy. Cinzia Ragni [cinziaragni93@gmail.com], Via Serponte 21, Cameri, Novara, Italy.

This is an open-access article distributed under the terms of the Creative Commons Attribution License (for details please see creativecommons.org), which permits unrestricted use, 
distribution, and reproduction in any medium, provided the original author and source are credited.

Faf Full text $(1,498.5 \mathrm{kB})$ ।

Far Supplementary file $(1,939.9 \mathrm{kB})$ 